\title{
Causes and Consequences of Ecosystem Service Regionalization in a Coastal Suburban Watershed
}

\author{
W. M. Wollheim • M. B. Green • B. A. Pellerin • \\ N. B. Morse • C. S. Hopkinson
}

Received: 29 July 2012 /Revised: 15 May 2013 / Accepted: 16 May 2013 / Published online: 7 June 2013

(C) The Author(s) 2013. This article is published with open access at Springerlink.com

\begin{abstract}
The demand for ecosystem services and the ability of natural ecosystems to provide those services evolve over time as population, land use, and management practices change. Regionalization of ecosystem service activity, or the expansion of the area providing ecosystem services to a population, is a common response in densely populated coastal regions, with important consequences for watershed water and nitrogen $(\mathrm{N})$ fluxes to the coastal zone. We link biophysical and historical information to explore the causes and consequences of change in ecosystem service activity - focusing on water provisioning and $\mathrm{N}$ regulation - from 1850 to 2010 in a coastal suburban watershed, the Ipswich River watershed in northeastern Massachusetts, USA. Net interbasin water transfers started in the late 1800s due to regionalization of water supply for use by larger populations living outside the Ipswich watershed
\end{abstract}

W. M. Wollheim · N. B. Morse

Department of Natural Resources and Environment,

University of New Hampshire, Durham, NH 03824, USA

W. M. Wollheim $(\varangle) \cdot$ N. B. Morse

Earth Systems Research Center, Institute for the Study of Earth,

Oceans, and Space, University of New Hampshire,

Durham, NH 03824, USA

e-mail: wil.wollheim@unh.edu

\section{B. Green}

Center for the Environment, Plymouth State University,

Plymouth, NH, USA

M. B. Green

Northern Research Station, US Forest Service,

Durham, NH, USA

\section{B. A. Pellerin}

United States Geological Survey,

Sacramento, CA, USA

\section{S. Hopkinson}

Department of Marine Sciences, University of Georgia, Athens, GA 30602, USA boundaries, reaching a peak in the mid-1980s. Over much of the twentieth century, about $20 \%$ of river runoff was diverted from reaching the estuary, with greater proportions during drought years. Ongoing regionalization of water supply has contributed to recent declines in diversions, influenced by socioecological feedbacks resulting from the river drying and fish kills. Similarly, the N budget has been greatly perturbed since the suburban era began in the 1950s due to food and lawn fertilizer imports and human waste release. However, natural ecosystems are able to remove most of this anthropogenic $\mathrm{N}$, mitigating impacts on the coastal zone. We propose a conceptual model whereby the amount and type of ecosystem services provided by coastal watersheds in urban regions expand and contract over time as regional population expands and ecosystem services are regionalized. We hypothesize that suburban watersheds can be hotspots of ecosystem service sources because they retain sufficient ecosystem function to still produce services that meet increasing demand from the local population and nearby urban centers. Historical reconstruction of ecosystem service activity provides a perspective that may help to better understand coupled human-natural system processes and lead to more sustainable management of coastal ecosystems.

Keywords Ecosystem services $\cdot$ Regionalization · Watersheds · Water supply · Nitrogen regulation · Sources · Historical

\section{Introduction}

Humans depend on ecosystems for a wide range of basic services including food, water, fiber, and energy; the removal or breakdown of waste materials; and well-being through recreation or culture (Millenium Ecosystem Assessment Board 2005). Ensuring that ecosystem services are provided sustainably and with minimal unintended consequences to freshwater and coastal ecosystems will require a better understanding of where services 
are generated and used, the capacity of host ecosystems to generate services while increasingly impacted by human activities, and societal ability to adapt when capacity is exceeded (Chapin et al. 2009). Quantitative studies of ecosystem services provided by a place through time are needed to develop such knowledge. Such case studies can ultimately inform integrated analyses that account for trade-offs among multiple ecosystem services, their cumulative impacts, and feedbacks (Bennett et al. 2009; Nelson et al. 2009).

There is often a spatial disconnect between where ecosystem services are generated (i.e., sources) and their use, which can lead to considerable transfer of water and material across large distances (Peters et al. 2008; Lookingbill et al. 2009). Ecosystem service use is concentrated in or near population centers, which may overwhelm local ecosystem capacity to supply services. As a result, services for urban areas are obtained from further away or replaced altogether by artificial means (Peet 1969; Grimm et al. 2008a). The dislocation of sources and sinks arising from ecosystem service regionalization (or globalization) impacts the material budgets of watersheds in both source and consuming regions (e.g., Weiskel et al. 2007), resulting in unintended consequences such as the drying of rivers, degradation of soils, concentrated pollution, and eutrophication (Diaz and Rosenberg 2008).

Suburbanization leads to dynamic changes in the distribution of ecosystem service source and use across the landscape. Whereas fully urban areas completely overwhelm the local capacity to generate ecosystem services, suburban areas may maintain much of this capacity. As suburban population grows in watersheds surrounding urban cores, demand for ecosystem services generated locally intensifies (e.g., Claessens et al. 2006). This local demand, combined with legacies of export to more urban areas nearby, can exacerbate imbalances in water and material budgets and intensify negative consequences (Glennon 2002). Communities must evaluate the trade-offs among multiple services and decide whether to maintain local sources or whether to implement broaderscale (e.g., regional) solutions. Suburban watersheds, therefore, provide a useful laboratory for understanding how regionalization of ecosystem services unfolds over time.

Here, we explore how regionalization of ecosystem services has evolved and impacted an urbanizing New England watershed over the past 160 years. We focus on two interacting services, water provisioning and nitrogen $(\mathrm{N})$ removal, each of which impacts hydrological and biogeochemical fluxes. Our objectives are to (1) characterize how ecosystem services provided by the watershed have evolved as urbanization in the region progressed, (2) quantify how watershed water and $\mathrm{N}$ budgets have been altered, and (3) explore the role of regionalization in coupled human-natural systems. Understanding these dynamics requires a historical perspective that combines modern scientific and historical information (Pastore et al. 2010; Bain et al. 2011).

\section{Methods}

\section{Study Site}

The Ipswich River watershed is the largest watershed flowing to the Plum Island Estuary in northeast Massachusetts, USA (Fig. 1). The watershed has a long post-European settlement history extending back 400 years and is now considered part of the Boston Metropolitan Area. The watershed has been intensively studied as part of the NSF Long Term Ecological Research Network (Plum Island Ecosystem [PIE]) since 1993 (Hopkinson and Vallino 1995; Kirwan et al. 2010). Climate is northern temperate, with mean annual precipitation of $1,180 \mathrm{~mm}$ year $^{-1}$ uniformly distributed throughout the year, mean annual runoff of about $590 \mathrm{~mm}$ year $^{-1}$, and mean annual temperature of $10{ }^{\circ} \mathrm{C}$ (Sammel 1967). The watershed sits in the Seaboard Lowland section of the New England physiographic province, with shallow soils and an abundance of wetlands (Williams et al. 2004).

The Ipswich River watershed has a drainage area of $404 \mathrm{~km}^{2}$. It is currently home to roughly 130,000 people (2000 census), living mainly in low-density to moderate-density suburban neighborhoods (MassGIS, http://www.mass.gov/mgis/). Much of the population growth occurred since the 1950s (Figs. 1 and 2). Roughly $40 \%$ of human sewage waste in 2000 was exported from the basin via sewers, while $60 \%$ entered the watershed via septic systems (Williams et al. 2004). Land use in 2000 included forest $(\sim 35 \%)$, agriculture $(\sim 7 \%)$, residential $(\sim 30 \%)$, wetlands ( $20 \%$ ), industrial $(\sim 4 \%)$, and open water ( 3\%) (MassGIS). As in much of Massachusetts, agricultural land use was historically high, peaking at $\sim 70 \%$ of land area in the mid-1800s and beginning a slow decline to modern times (Hall et al. 2002; Foster et al. 2003a). The watershed is surrounded by more densely populated communities, including Salem, Lynn, and Boston and its inner suburbs to the south, and a string of urban centers along the Merrimack River to the north (including Newburyport, Haverhill, Lawrence, and Lowell) (Fig. 1). These surrounding areas have been densely populated since before the mid-1800s.

\section{General Approach}

We quantify at the watershed scale whether ecosystem services are exported, imported, or locally generated and used over time. The partitioning of ecosystem services in these categories serves as an indicator of regionalization. Watersheds integrate ecosystem processes and the effects of human activities across the landscape via hydrologic transport (Likens and Bormann 1974). Thus, quantification 
Fig. 1 Watersheds in northeastern MA draining to the Plum Island Estuary, showing town population density in 40 year increments between 1880 and 2000. The more southern watershed is the Ipswich River, while the northern watershed, much of which is tidal, is the Parker River. Boston and other coastal urban centers are to the south, while the Merrimack

River watershed is to the north

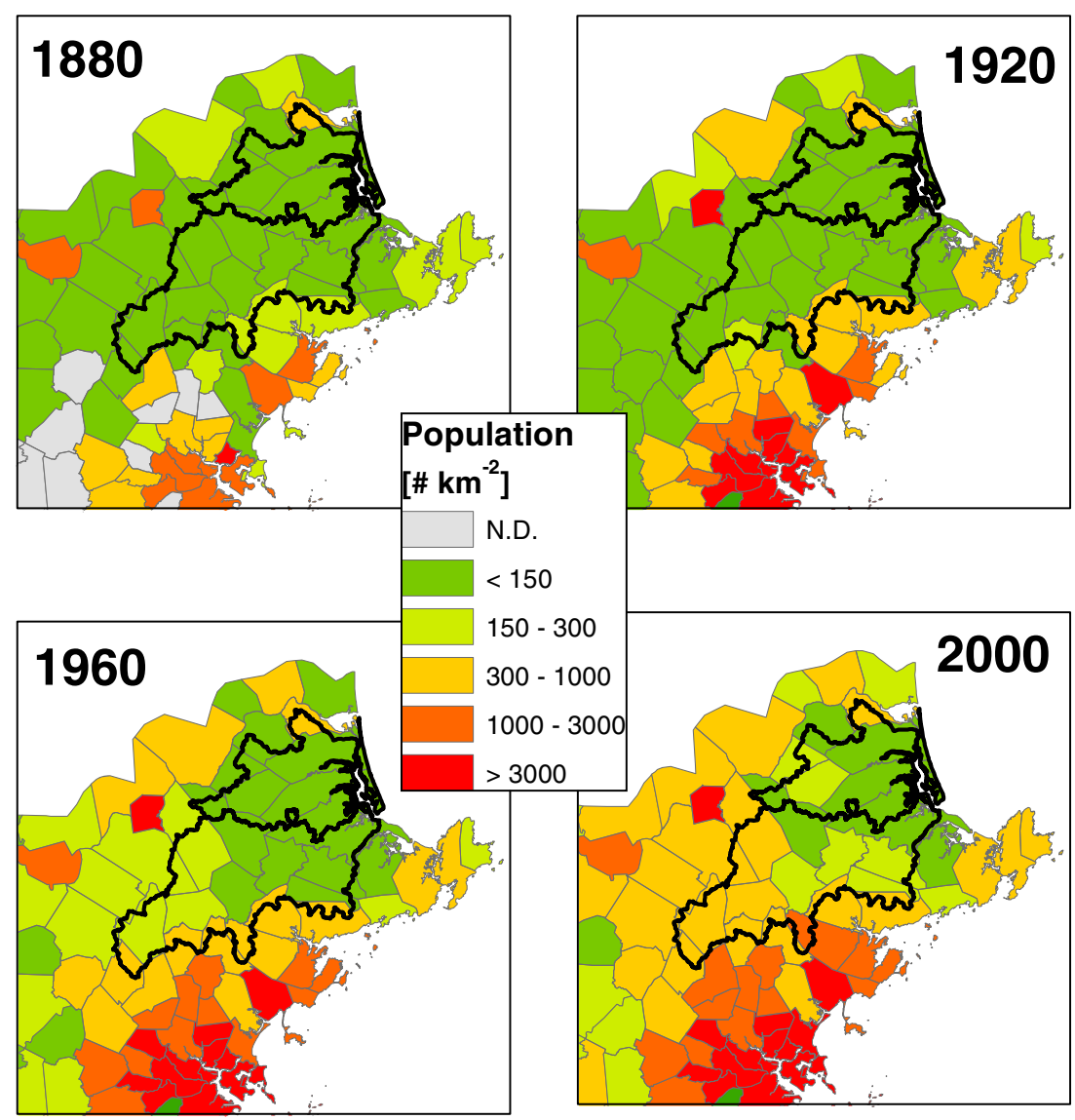

of ecosystem service source and use at watershed scales can improve understanding of the impacts to downstream freshwater and marine systems due to altered material flows (Lookingbill et al. 2009) and modification of ecosystem characteristics that regulate within basin flows (Jones et al. 2000; Blanton and Marcus 2009). The analysis is inherently spatial and could be used at finer (e.g., subwatershed) or broader (multiple watershed) spatial scales. However, we

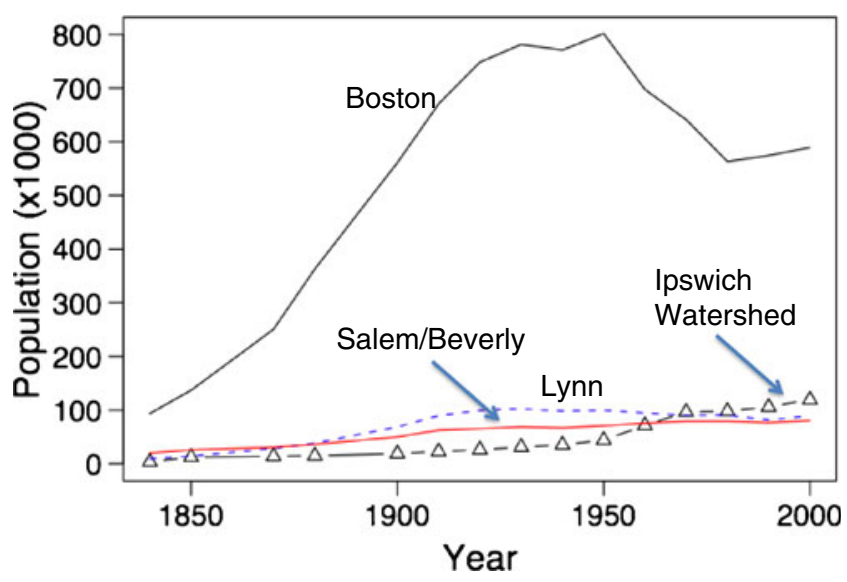

Fig. 2 Population trend in the Ipswich River watershed and selected cities to the south between 1850 and 2000. Salem/Beverly and Lynn rely on Ipswich water for their water supply demonstrate here the approach for a single watershed defined by its basin mouth at the coastal zone.

We partition for each ecosystem service the amount that is (1) exported from within the watershed to people outside the watershed (donor watershed), (2) imported from outside the watershed to people within the watershed (recipient watershed), and (3) locally generated and benefits people within the same watershed (Table 1). We track how the magnitude and mix of each changes through time. Watersheds can be a mixture of all three categories simultaneously (i.e., a donor, recipient, or local), depending on the distribution of sources and use within the watershed and the scale being considered (i.e., size of the watershed). This partitioning can potentially be applied to different ecosystem service types.

\section{Application}

We apply this approach to the ecosystem services of water supply (provisioning) and $\mathrm{N}$ removal (regulating). Water supply is a provisioning service with an obvious human benefit. $\mathrm{N}$ removal is a regulating service that mitigates downstream pollution impacts when excess $\mathrm{N}$ is introduced into the environment (Brauman et al. 2007). $\mathrm{N}$ removal processes include long-term storage or denitrification by terrestrial and aquatic ecosystems (Galloway et al. 2003; Seitzinger et al. 2006). For these services, we have sufficient 
Table 1 Categories of ecosystem service from a watershed perspective

\begin{tabular}{|c|c|c|c|}
\hline Watershed type & Description & Internal dynamics & Examples \\
\hline Donor (exporter) & $\begin{array}{l}\text { A service produced by the } \\
\text { watershed is used by } \\
\text { people living outside the } \\
\text { watershed boundaries }\end{array}$ & $\begin{array}{c}\text { Internal sources } \\
\text { local demand }\end{array}$ & $\begin{array}{l}\text { Provision: water from rural watershed supplied to city in different } \\
\text { watershed (e.g., Boston, NYC) } \\
\text { Regulating: waste N generated outside the watershed is transferred to } \\
\text { and denitrified by ecosystems within the watershed } \\
\text { Cultural: pristine river in rural watershed visited by residents of urban } \\
\text { watershed for recreation }\end{array}$ \\
\hline $\begin{array}{l}\text { Recipient } \\
\text { (importer) }\end{array}$ & $\begin{array}{l}\text { A service produced outside } \\
\text { the watershed is used by } \\
\text { people living inside the } \\
\text { watershed }\end{array}$ & $\begin{array}{l}\text { Local demand» } \\
\text { internal sources }\end{array}$ & $\begin{array}{l}\text { Provision: population in urban watershed obtains water from distant } \\
\text { rural watershed } \\
\text { Regulating: waste } \mathrm{N} \text { generated in urban watershed is exported to } \\
\text { neighboring watershed where it is released and denitrified } \\
\text { by ecosystem processes } \\
\text { Cultural: people living in an urban watershed visit a rural watershed } \\
\text { for recreation }\end{array}$ \\
\hline $\begin{array}{l}\text { Internal user } \\
\text { (local) }\end{array}$ & $\begin{array}{l}\text { A service produced inside } \\
\text { the watershed is used by } \\
\text { people living inside the } \\
\text { watershed }\end{array}$ & $\begin{array}{l}\text { Local demand } \sim \\
\text { internal sources }\end{array}$ & $\begin{array}{l}\text { Provision: water from well on property or local river } \\
\text { Regulating: population releases waste } \mathrm{N} \text { into groundwater through } \\
\text { septic systems } \\
\text { Cultural: canoeing in local pond or river }\end{array}$ \\
\hline
\end{tabular}

quantitative information to reasonably partition source and fate at the watershed scale back to 1850 , the point in time just prior to the first known interbasin water transfers (Longley 1916). We consider the $\mathrm{N}$ removal service as imported when $\mathrm{N}$ is transferred out of the basin (e.g., people inside the basin benefit when $\mathrm{N}$ is exported and removal is performed elsewhere) and consider it as exported when $\mathrm{N}$ is transferred into the basin (people outside the watershed benefit by removal within the watershed; Table 1). Import/export of $\mathrm{N}$ removal is generally associated with movement of sewage across watershed boundaries.

Other ecosystem services have been or continue to be important in the watershed (e.g., food production, recreation, biofuel production, carbon sequestration, air quality maintenance; Farber et al. 2006), but are not the focus here. Food provisioning by the watershed was important as evidenced by historical agricultural land use, much of which was likely exported to nearby urban centers. However, it is clear that, during the suburban era, food imports are the major influence on the $\mathrm{N}$ budget and the need for $\mathrm{N}$ removal services (Williams et al. 2004). We focus on $\mathrm{N}$ rather than phosphorus (P) because coastal areas are N limited (Vitousek and Howarth 1991) and P is not affected by human activity in this watershed (Williams et al. 2005).

\section{Water Provision Quantification}

Water supply decisions are made at the town scale in the Ipswich watershed. To construct the time line of local, imported, or exported water supply, we compiled data on water use and source by town. We used town water records for 1934-2000 previously compiled by Claessens et al. (2006), extended back to 1850 using documented sources (Longley 1916), and through 2008 using town records from the MA Department of Environmental Protection. The fate of water supply back in time was partitioned as internal or external to the watershed using town population (US Census) relative to watershed boundaries. For towns that straddle the divide, we used present-day land use distribution to partition internal vs. external use. This approach may somewhat overestimate internal water use back in time, since disproportionate population growth in recent years occurred outside the more urban town areas, which are external to the watershed. This affects only a few towns, and in these, most population continues to reside outside the boundaries (e.g., $78 \%$ of Reading in 2000 live outside the boundaries), so error due to this assumption is likely minimal. We estimated infiltration losses through sewer systems by assuming a constant infiltration rate in communities with sewers (infiltration ratio of $65 \%$ ), based on an average of three communities in the 1990s (Claessens et al. 2006). Infiltration may change as infrastructure ages, but we have no estimates of changes through time. Errors associated with this assumption would impact estimates since the late 1960s when sewers were constructed.

Town-level information was aggregated to the watershed scale to estimate gross water exports (Export ${ }_{\text {gross }}$ ) and imports (Import gross $_{\text {). Net exports are calculated as }}$ Export $_{\text {net }}=$ Export $_{\text {gross }}-$ Import $_{\text {gross }}$. The proportion of total watershed runoff diverted from the estuary is calculated as 


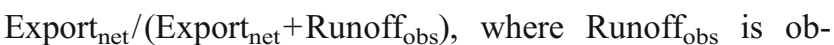
served runoff obtained from the USGS gage at Ipswich (gage number 01102000) from 1934 to 2009. All units are standardized to depth/time [in millimeters per year] by dividing flow volumes by watershed area $\left(404 \mathrm{~km}^{2}\right)$ to make the quantities independent of watershed size as in previous studies and to allow easy comparison to precipitation (Claessens et al. 2006). We assumed runoff measured at the USGS gage $\left(340 \mathrm{~km}^{2}\right)$ applied to the ungaged area as well. We also assumed that the mean total watershed runoff for the 1934 to 1954 period could be applied back in time. This assumption is reasonable as century scale climate and hydrological analysis suggests that little or no climate trends occurred during the early part of the twentieth century (Huntington et al. 2009). Regrowing forests during the late nineteenth to mid-twentieth century may have affected runoff through increasing evapotranspiration. However, Runoff $f_{\text {obs }}$ did not trend during the early gage period when withdrawals were stable and forests were regrowing $(p=0.83)$, suggesting the assumption of stationarity prior to the gage period is reasonable.

\section{Nitrogen Removal Quantification}

We constructed a time series of watershed $\mathrm{N}$ removal based on net $\mathrm{N}$ inputs to the watershed and fluvial $\mathrm{N}$ exports (in kilograms $\mathrm{N}$ per square kilometer per year). Net $\mathrm{N}$ input $\left(\mathrm{Nin}_{\text {net }}\right)$ is calculated as $\mathrm{Nin}_{\text {gross }}-\mathrm{Nout}_{\text {sewer }}-\mathrm{Nout}_{\mathrm{ws}}$, where

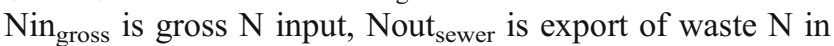
sewers, and Nout ${ }_{\mathrm{ws}}$ is export of $\mathrm{N}$ in exported water supply. $\mathrm{Nin}_{\text {gross }}=\mathrm{Nin}_{\mathrm{atm}}+\mathrm{Nin}_{\text {fert }}+\mathrm{Nin}_{\text {food, }}$, where $\mathrm{Nin}_{\text {atm }}$ is atmospheric input, $\mathrm{Nin}_{\text {fert }}$ is fertilizer input, and $\mathrm{Nin}_{\text {food }}$ is food import that enters the watershed through human waste. The $\mathrm{N}$ removal ecosystem service as a proportion of inputs at the watershed scale ( $\mathrm{ES}_{\text {nrem; }}$ unitless) is then calculated as $\mathrm{ES}_{\text {nrem }}=1-\mathrm{Nout}_{\text {river }} / \mathrm{Nin}_{\text {net }}$, where Nout ${ }_{\text {river }}$ is riverine $\mathrm{N}$ export at the mouth of the watershed.

For $\mathrm{Nin}_{\mathrm{atm}}$, we used measurements of wet deposition from the nearby NADP site (Lexington, MA, USA), combined with an $\mathrm{N}$ deposition model (Bowen and Valiela 2001), which also accounts for dry deposition and DON deposition. This model showed linear rates of increase between 1910 and 2000, which we extrapolated back in time.

For $\mathrm{Nin}_{\text {fert }}$, we used county-level fertilizer estimates from 1982 to 2001 (Ruddy et al. 2006) and from 1945 to 1985 (Alexander and Smith 1990). The two fertilizer N products differ somewhat in their estimates where they overlap. Because it is more recent, we used the fertilizer estimates of Ruddy et al. (2006) (farm+nonfarm) for 1982 to present (in kilograms $\mathrm{N}$ per square kilometer per year) and scaled 1982 values back in time using the year-to-year change relative to 1982 from Alexander and Smith (1990). For
2001 to 2008, we assumed that fertilizer applications were constant. For years prior to 1945 , we scaled fertilizer imports to 1850 , assuming the same rate of decline as in the nearby Narragansett watershed (Vadeboncoeur et al. 2010; 0.016 year $^{-1}$ ). Both regions experienced similar rates of land use change during this period (Hall et al. 2002). We assumed that the county data (Essex County, MA, USA) were representative for the entire Ipswich River watershed.

For $\mathrm{Nin}_{\text {food, }}$, we used town-level population back to 1850 (US Census) and assumed a constant per capita waste emission of $4.8 \mathrm{~kg} \mathrm{~N}_{\text {person }}{ }^{-1}$ year $^{-1}$ (Valiela et al. 1997; Nixon et al. 2008). Population was scaled to watershed boundaries as described previously for water supply. To calculate

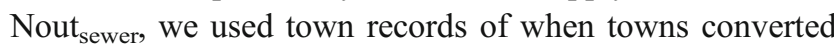
from local waste management (e.g., septic) to municipal sewage waste management. All sewered $\mathrm{N}$ is exported from this watershed (Williams et al. 2004). We assumed that food $\mathrm{N}$ has been primarily imported from outside the basin throughout our study period. This assumption is valid for most of the suburban era (Bahn and Christensen 1979), but likely did not hold during the late 1800s and early 1900s. Violation of this assumption would imply lower $\mathrm{N}$ import in earlier periods since more $\mathrm{N}$ was locally derived. But since population was low during this time (Fig. 2), violation of this assumption does not affect the interpretation of our results. We also assumed that (1) net feed imports for animal products were small, with feed locally grown within the watershed in pasture and extensive freshwater marshes (Vadeboncoeur et al. 2010; Donahue 2004), and (2) both agricultural and forest $\mathrm{N}$ fixation were small terms given that nonleguminous species dominate in this region (US Census 1925; Boyer et al. 2002).

We constructed a simple annual model of $\mathrm{ES}_{\mathrm{nrem}}$ as a function of runoff. We first calculated annual Nout river $_{\text {from }}$ the Ipswich River watershed using N concentrations collected by the PIE LTER since 1993 (http://ecosystems.mbl.edu/ pie/data.htm) and USGS discharge information. We used the USGS LOADEST program (Runkel et al. 2004) to calculate the annual total dissolved $\mathrm{N}$ export flux at the basin mouth based on daily discharge, time of year, and monthly measurements of concentrations. Particulate $\mathrm{N}$ is a small component of the fluvial export fluxes $(<10 \%)$, even in high-flow years (Williams et al. 2004) and so is here ignored. Nout ${ }_{\mathrm{ws}}$ was calculated using Nout $_{\text {river }}$ and the proportion of annual water runoff diverted from the basin. Most water withdrawals occur along the main stem where nutrient concentrations are relatively constant. Annual $\mathrm{N}$ removal (in kilograms $\mathrm{N}$ per square kilometer per year) for the period of nutrient record (1993 to present) was then estimated as the difference between $\mathrm{Nin}_{\text {net }}$ and Nout ${ }_{\text {river }}$ We related $\mathrm{ES}_{\text {nrem (unitless) to annual watershed runoff using linear }}$ regression analysis. This model was then used to extend our estimates of $\mathrm{ES}_{\text {nrem }}$ prior to 1993 using USGS runoff. 


\section{Results}

\section{Water Provisioning Ecosystem Service}

Prior to 1868 , water sources within the watershed were for local use only. In 1868, the cities of Salem and Beverly, with populations outside the basin boundary, tapped into Wenham Lake, within the southern boundary of the Ipswich River watershed, to obtain adequate water for their growing populations (Fig. 2). This initiated water export to populations outside the basin that continues to the present (Fig. 3). Export intensified in the late 1910s when the Salem/Beverly Canal was dug, and when the city of Lynn, located south of the boundary, also tapped into the Ipswich River main stem. Between 1920 and 1981, these two exports ranged between 60 and $73 \mathrm{~mm}_{\text {year }}{ }^{-1}$ (representing 5-6\% of average annual precipitation and 9-11\% of annual runoff).

Both exports and internal use increased steadily in the early 1960 s as suburbanization accelerated in towns along the southern boundary of the watershed, all of which used Ipswich water sources. Because some of these communities straddled the watershed boundaries, both exports and local use accelerated (Fig. 3). These suburban communities withdrew water throughout the year, intensifying in summer due to lawn watering and other uses (e.g., car washing, pools).

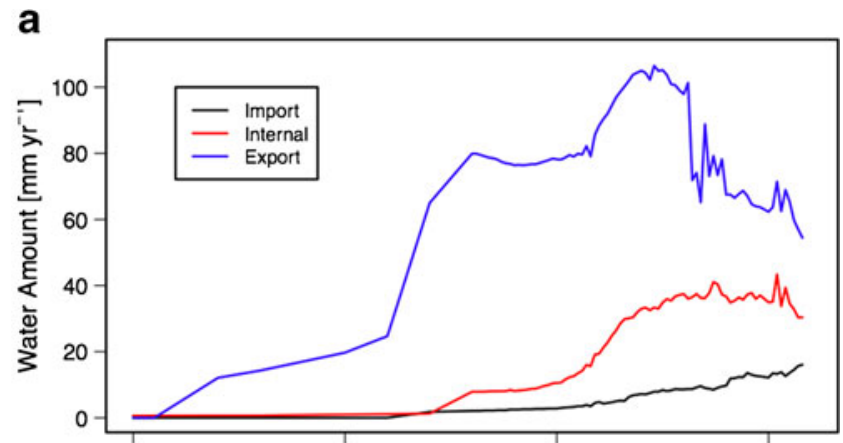

b

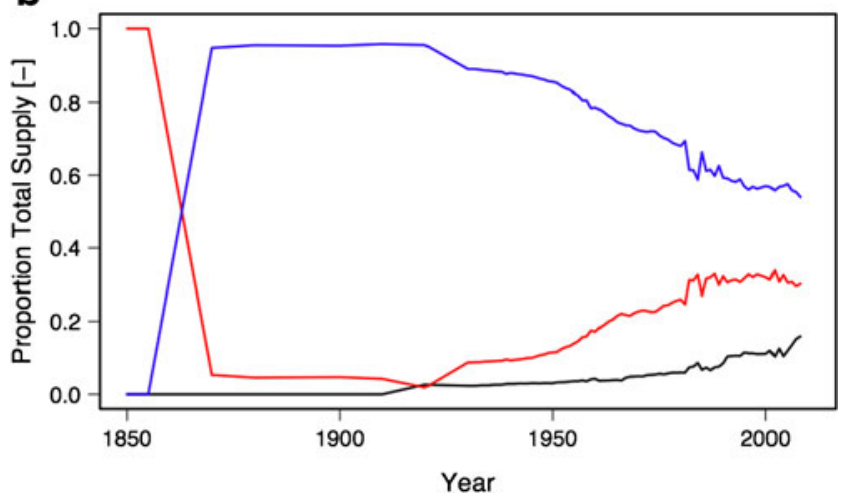

Fig. 3 Water provisioning ecosystem service in the Ipswich River watershed, showing a annual water supply imported, exported, and used internally (in millimeters per year) and $\mathbf{b}$ proportion of total water supply exported, imported, and used internally
Total water provisioning from within the basin boundaries peaked in $1980\left(\sim 140 \mathrm{~mm}_{\text {year }}{ }^{-1}\right.$, of which $100 \mathrm{~mm}^{\text {year }}{ }^{-1}$ was exported).

Since 1980, both the internal use and export of water has been stable or declining. In contrast, import of water to the basin continues to slowly increase, now representing almost $20 \%$ of all water use (Fig. 3b). Imported water prior to 2000 was primarily from the Merrimack Watershed to the north. Since 2000, two communities joined the Massachusetts Water Resources Authority (MWRA), the regional water provider of Boston and its closest suburbs, and now also obtain water from outside the basin. The net effect is that roughly $20 \%$ of annual runoff was diverted from the watershed since 1934, but declining in recent years (Fig. 4). The annual proportion diverted varies from year to year due to climate variability, approaching $60 \%$ of annual runoff during droughts because withdrawals are steady or even increase in dry years.

\section{Nitrogen Regulating Ecosystem Service}

The Ipswich River watershed has undergone considerable population growth since the 1950s (Fig. 1; Schneider and Pontius 2001), resulting in accelerated import of food and fertilizer N (Fig. 5). Gross $\mathrm{N}$ inputs increased steadily since 1950 (increasing by $23 \mathrm{~kg} \mathrm{~km}^{-2}$ year $^{-1}$ ), aside from a downward dip in the late 1970s (Fig. 5b). This dip occurred because fertilizer inputs took a sharp drop in 1979 (Alexander and Smith 1990), coinciding with spikes in fuel prices during the second oil shock of the 1970s and the recession of the early 1980s. Fertilizer use did not return to mid-1970s levels until 1994 (Fig. 5a).

In contrast, net inputs increased more slowly since 1950 (by $13 \mathrm{~kg} \mathrm{~km}^{-2}$ year $^{-1}$; Fig. 5b). The slower rate of increase in net $\mathrm{N}$ inputs is due to the development of sewer systems in some communities following the initial suburbanization in the 1950s (Fig. 5a). Because watershed communities with sewer systems are connected to treatment plants serving denser communities outside the basin, sewer construction

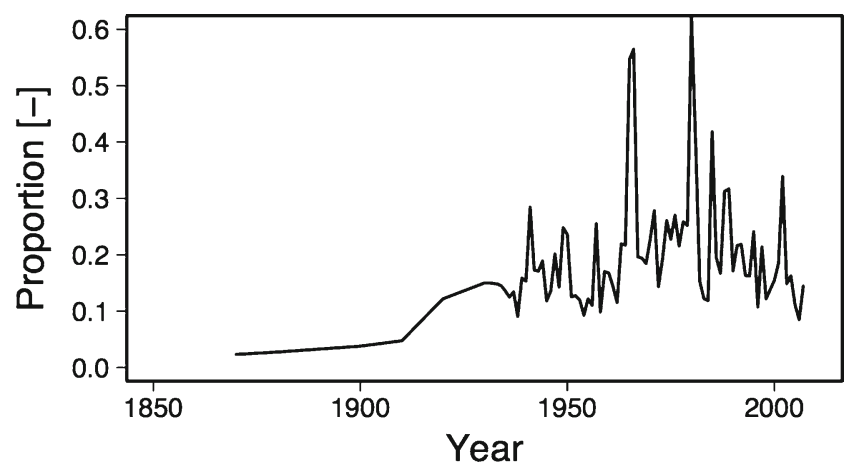

Fig. 4 Proportion of annual Ipswich River discharge diverted from the Plum Island Estuary for water supply outside its watershed boundaries 
resulted in $\mathrm{N}$ diversion ( $17 \%$ of gross inputs in 2000). Since 1950, both gross and net $\mathrm{N}$ inputs have increased at a slower rate (16 and $8 \%$ decade $^{-1}$, respectively) than population $\left(35 \%\right.$ decade $\left.^{-1}\right)$.

Proportional watershed-scale N removal since 1994 was $>80 \%$ of net annual $\mathrm{N}$ inputs but is inversely related to annual runoff (Proportional N removal $=0.97-0.000195 \times$ runoff, $R^{2}=0.91, p<0.05$; Fig. 6). This relationship is based on the 1994-2008 period, which encompasses most of the range of annual runoff over the period of record (1934 to present), including the record high annual runoff in 2006. The 1994-2008 period also incorporates the effect of elevated $\mathrm{N}$ loading and suburban land use change and, therefore, accounts for the effects of impervious surfaces and $\mathrm{N}$ saturation (Wollheim et al. 2005; Mulholland et al. 2008). The relationship (Fig. 6) is thus likely to be a conservative estimate of $\mathrm{N}$ removal during earlier lower $\mathrm{N}$ load periods. However, because runoff conditions are such a strong control, we believe the model is a good representation of $\mathrm{N}$ removal throughout the analysis period.

Absolute amounts of watershed $\mathrm{N}$ removal increased since the onset of suburbanization in the 1950s. Annual watershed $\mathrm{N}$ removal increased from $\sim 1,500$ to over 2,300 kg N km${ }^{-2}$ year $^{-1}$ (606-929 $\mathrm{mT} \mathrm{year}^{-1}$ ) between 1940 and 1965 and was only moderately higher in 2000 $\left(\sim 2,500 \mathrm{~kg} \mathrm{~N} \mathrm{~km}^{-2}\right.$ year $^{-1}$; Fig. 7a). The mass of $\mathrm{N}$ removed by watershed ecosystems was four to five times higher than $\mathrm{N}$ transferred out of the basin via sewers in 2000 $\left(\sim 500 \mathrm{~kg} \mathrm{~km}^{-2}\right.$ year $\left.^{-1}\right)$, which represents an engineered replacement of natural ecosystem services (Fig. 7a).

Despite the effectiveness of the watershed to regulate $\mathrm{N}$ (Fig. 6), $\mathrm{N}$ fluxes to the estuary increased steadily because net $\mathrm{N}$ inputs increased while the removal relationship was assumed constant (Fig. 7b). Between 1940 and 1950, annual flux to the estuary averaged $184 \mathrm{~kg} \mathrm{~km}^{-2}$ year $^{-1}$ $\left(74 \mathrm{mT}\right.$ year $\left.^{-1}\right)$, while between 2000 and 2007, it averaged $438 \mathrm{~kg} \mathrm{~km}^{-2}$ year $^{-1}\left(177 \mathrm{mT}\right.$ year $\left.^{-1}\right)$. High runoff and associated lower removal proportions in recent years contribute to elevated fluxes. We estimate that the highest flux ever was in 2006 due to record high precipitation and runoff.

Prior to 1965 , the $\mathrm{N}$ regulating ecosystem service was largely local; $\mathrm{N}$ was primarily released and removed within the watershed. With intensified suburbanization in the 1960 s, local ecosystem services began to be replaced with regional solutions (i.e., sewers) that diverted $\mathrm{N}$ from the basin (Fig. 7c), requiring natural and engineered systems beyond the watershed to mitigate impacts. Net water withdrawal from the basin (Fig. 3) is an additional small fate of total $\mathrm{N}$ inputs, albeit fairly significant relative to riverine fluxes to the estuary (Fig. 7b). Overall, ecosystems internal
Fig. $5 \mathrm{~N}$ inputs to the Ipswich River watershed between 1850 and 2008, showing amounts of a various $\mathrm{N}$ sources and $\mathbf{b}$ gross and net $\mathrm{N}$ inputs

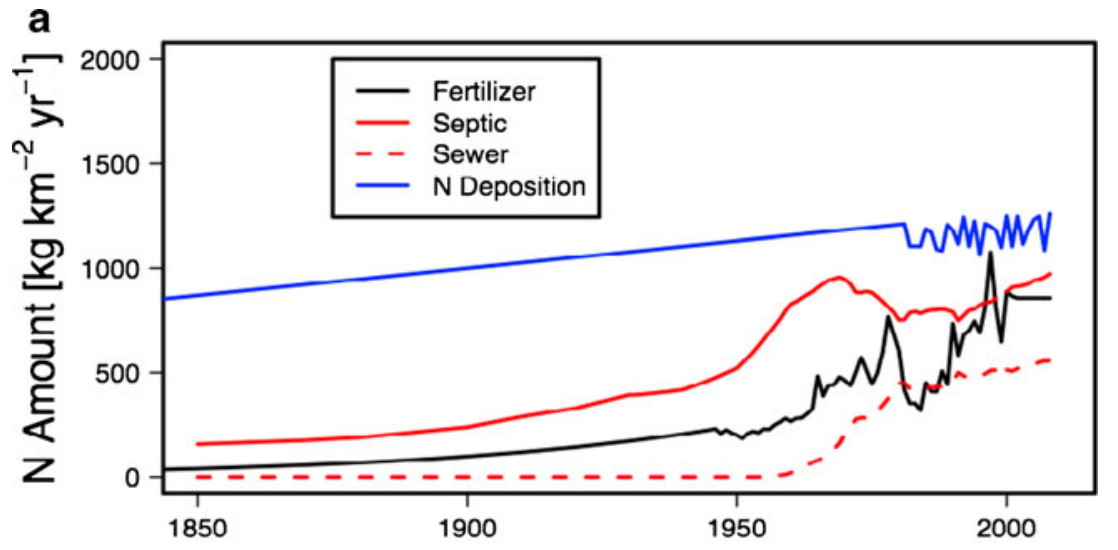

b

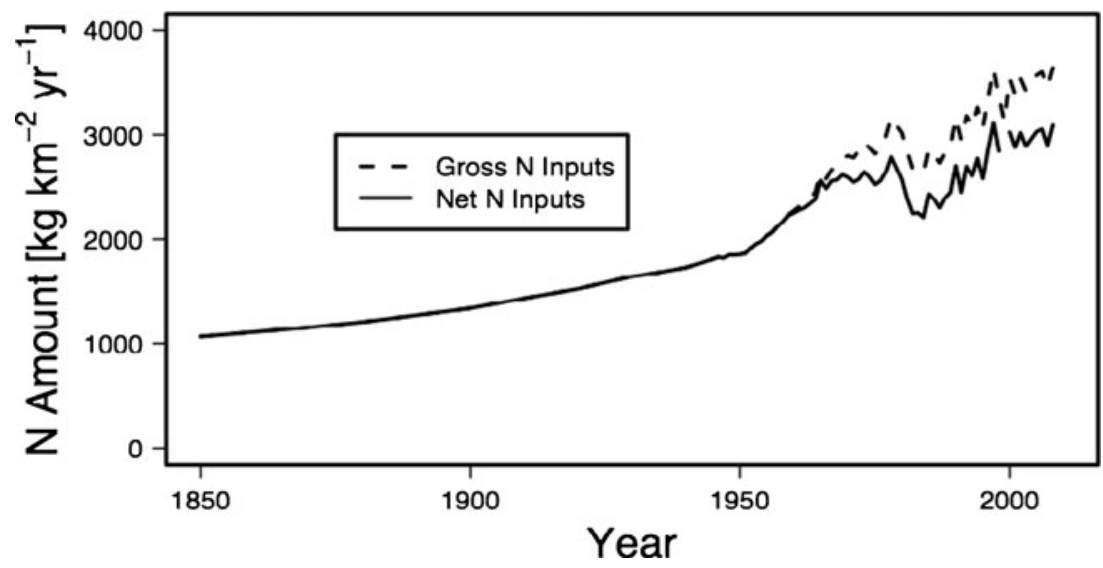


Fig. 6 Annual $N$ removal as a function of annual runoff between 1994 and 2008

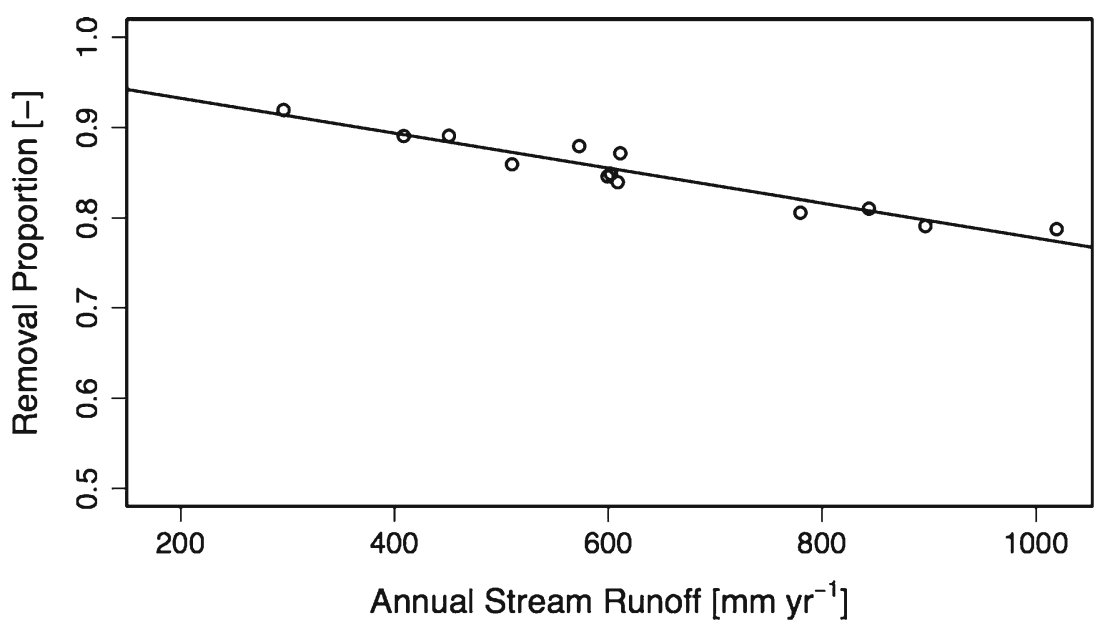

to the watershed continue to be the primary regulators of $\mathrm{N}$ export to the estuary-hence, the ecosystem service remains primarily local.

\section{Discussion}

Regionalization and the Watershed as Provider or Recipient of Ecosystem Services

The form and amount of ecosystem services used by communities or produced within a watershed evolves over time as societal need and ability to procure services change (Farber et al. 2006; Beier et al. 2008). Regionalization is one of the mechanisms contributing to this evolution (Peet 1969), helping to explain the trajectory of ecosystem services provided by the Ipswich watershed over the past 160 years. Early European settlement in Massachusetts, as in the rest of North America, began in coastal regions with suitable harbors or at the mouths of large rivers (Doyle 2012). For example, the port cities of Boston, Salem, Gloucester, and Newburyport, all within $30 \mathrm{~km}$ of the Ipswich watershed, were among the 15 largest American cities in 1790 (US Census 1998), with Salem (seventh largest in 1790) as the largest user of Ipswich River water through time. During industrialization in the early 1800 s, a second wave of urban centers was established inland along rivers with adequate hydropower (e.g., Haverhill, Lawrence, and Lowell along the Merrimack River, also within $30 \mathrm{~km}$ to the north). In contrast, the Ipswich watershed is not linked to a large harbor or river and is too shallow-sloped to provide significant hydropower, so no large population centers developed until the suburban era (Fig. 2).

Urban centers outstrip their local ecosystem's capacity to provide services and must resort to obtaining them from increasingly distant locations or using technological fixes (Grimm et al. 2008b). Water supply for large urban centers such as Boston, New York, and other major cities are well- known examples. In the case of Boston, the city tapped watersheds in a westward progression over time, and now obtains its water from western MA (MDC 1984). The cities of Salem and Lynn met their water needs from the Ipswich River watershed, which was close, rural, and large enough to ensure sufficient clean water (Longley 1916). Boston had also considered the Ipswich River watershed as a potential source in the early 1900 s but concluded it was insufficient to meet the projected needs (MDC 1984). For similar reasons, the Ipswich and adjacent Parker watersheds were likely a source of food provisioning ecosystem services to the more densely settled surrounding region in the nineteenth century (Rothenberg 1992) and for some food products into the twentieth century (Bahn and Christensen 1979), although the amount exported at the watershed scale cannot be readily quantified.

Prior to the suburban era, the watershed was predominantly an exporter of ecosystem services for the more urban regions beyond its boundaries. This changed with suburbanization, both because of increasing use of local watershed ecosystem services (water supply, nutrient regulation) and imports (food provisioning, water). While initially the use of local ecosystem services intensified, the watershed is now regionalizing as did more urban areas previously, reflected in increasing water imports, declining water exports, and import of $\mathrm{N}$ removal via sewer systems. Ongoing regionalization in suburban watersheds differs from the urban core because existing infrastructure previously developed by the urban core is being used, making substitution of locally derived ecosystem services relatively easy and cost effective (see the succeeding section).

Impact of Regionalization on Watershed Budgets

Spatial divergence between ecosystem service sources and their use is common, and depending on the magnitude, watershed-scale material budgets can be altered (Weiskel et al. 2007; Lookingbill et al. 2009). Both water and $\mathrm{N}$ 
Fig. 7 Watershed-scale N removal in the Ipswich watershed over time. a Annual fate of watershed gross $\mathrm{N}$ inputs, $\mathbf{b}$ annual flux of $\mathrm{N}$ exported from the watersheds in natural flows and water withdrawals, and $\mathbf{c}$ proportion of $\mathrm{N}$ removal occurring via natural (internal) and anthropogenic (exported) processes. Curves are smooth prior to 1934 because we assume mean annual water flow prior to the initiation of the observational record
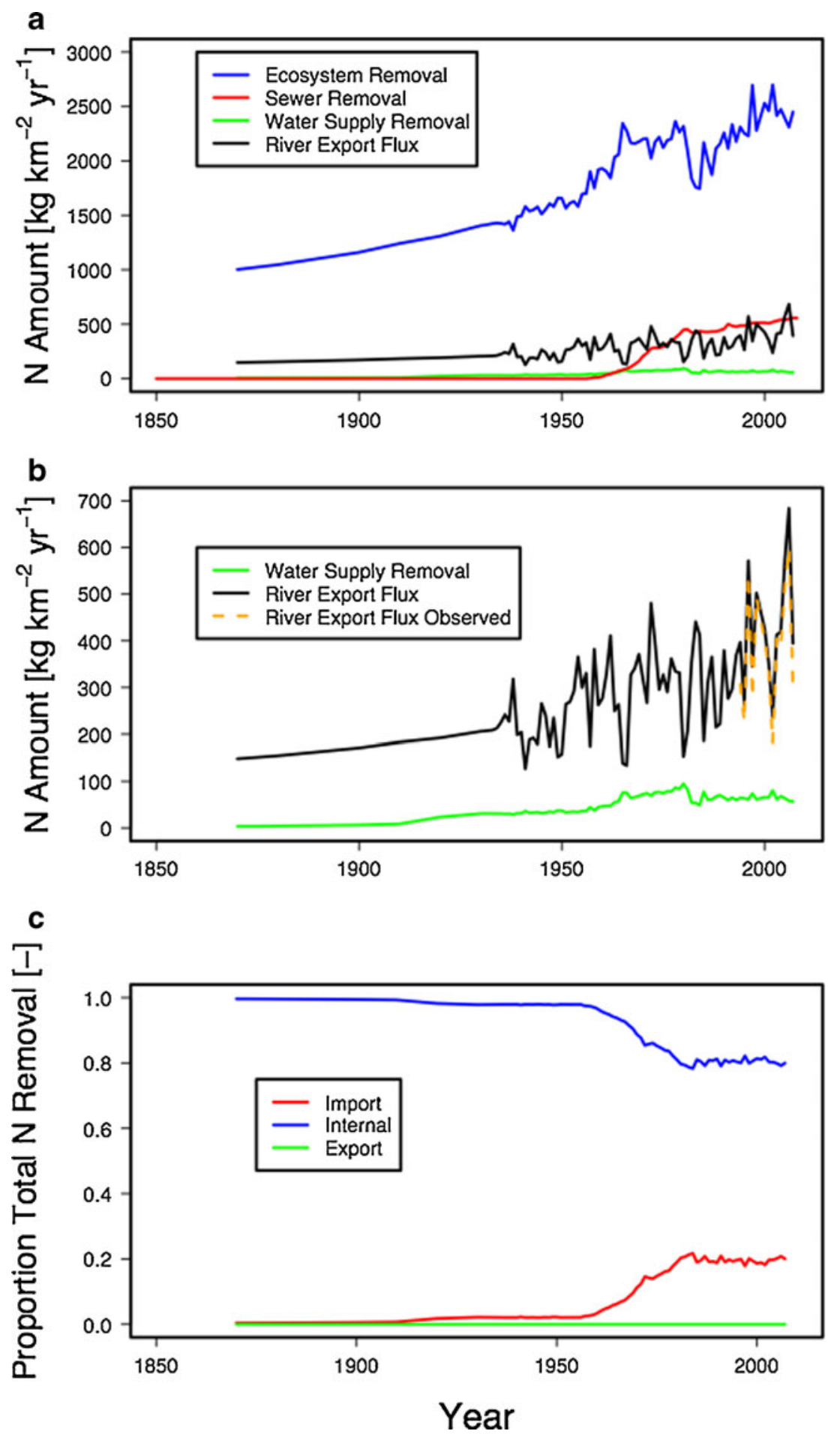

budgets in the Ipswich watershed have been perturbed due to regionalization of water and food. While the contemporary watershed remains a source of water for both local and export use, it is an importer of food provisioning, the major term in the $\mathrm{N}$ budget here and elsewhere in the northeast (Boyer et al. 2002; Williams et al. 2004). As a consequence, annual water flow at the basin mouth has been reduced $\sim 20 \%$ absent any diversion, while riverine $\mathrm{N}$ fluxes to the coastal zone have increased twofold to threefold. The $\mathrm{N}$ budget has been more perturbed than the water cycle in this suburban system, as is the case globally (Rockstrom et al. 2009).

Although these perturbations are large, they would have been greater if not for other offsetting environmental changes and the continued effectiveness of the $\mathrm{N}$ removal ecosystem service. Environmental change may have 
enhanced the capacity of local ecosystems to provide ecosystem services. For example, increased precipitation and impervious surfaces associated with suburbanization enhance runoff (Burges et al. 1998; Paul and Meyer 2001). Claessens et al. (2006) found that both these factors offset the increased net withdrawals in the Ipswich watershed, resulting in no net change in annual runoff over the period of record. Precipitation has increased in other areas (Karl and Knight 1998; Gedney et al. 2006), potentially leading to greater water supply. However, impervious surfaces may also degrade water quality, reducing the utility of the increase in water from precipitation (Paul and Meyer 2001).

Water provisioning activity can also offset at watershed scales some of the impacts of an accelerated $\mathrm{N}$ cycle. In the Ipswich River, we assumed that the $\mathrm{N}$ content of water diversions is similar to that in river export because most withdrawals are either directly from the river or from near river wells (Zarriello and Ries 2000), where concentrations are similar to the basin mouth (Stewart et al. 2011). As a result, the proportion of riverine $\mathrm{N}$ flux diverted from the estuary is likely similar to the proportion of runoff diverted, or $\sim 20 \%$. While small relative to the total $\mathrm{N}$ budget (Fig. 7a), this is significant relative to flux to the estuary, particularly in drier years (Fig. 4).

Conversion from septic systems to centralized waste management can not only impact watershed nutrient budgets but also unintentionally alter water budgets. Conversion acknowledges that regulating services by natural ecosystems can be overwhelmed, including both dilution capacity and nutrient removal. Centralized waste management is an engineered solution requiring costly investment and management (Tarr et al. 1984). The resulting reductions in nutrient inputs to a watershed can be large, as when nutrients are exported from the basin via sewer lines and treated elsewhere, or moderate, as when treated wastewater is released back within the basin (Weiskel et al. 2007). Centralized waste treatment can also exacerbate the net diversion of water if groundwater infiltration through sewer lines is significant (Lerner 2002; Claessens et al. 2006). Thus, replacement of local services ( $\mathrm{N}$ regulation) can exacerbate decline in other ecosystem properties and services (water flow and provision).

Despite the construction of sewer systems, natural ecosystem services continue to dominate the regulation of $\mathrm{N}$, as is the case globally (Fig. 7a; Galloway et al. 2003; Seitzinger et al. 2006). Urban and suburban watersheds retain a strong capacity to regulate $\mathrm{N}$, the mechanisms for which are not well understood (Groffman et al. 2004; Wollheim et al. 2005; Kaushal et al. 2008). Denitrification is a major fate of $\mathrm{N}$, although terrestrial $\mathrm{N}$ storage in biomass may also be significant (Van Breemen et al. 2002). However, the same factors that lead to enhanced water provisioning, i.e., greater runoff in a wetter climate, lead to reduced effectiveness of $\mathrm{N}$ removal (Fig. 6; Wollheim et al. 2005; Kaushal et al. 2008). Greater runoff tends to increase flushing and lower the residence time of water and nutrients, reducing the ability of biological processes to remove $\mathrm{N}$ (Doyle 2005; Fig. 6).

High watershed $\mathrm{N}$ removal rates suggest that this ecosystem service remains effective despite elevated $\mathrm{N}$ loading. The lack of an N saturation effect (Bernot and Dodds 2005) at the watershed scale may occur for several reasons. In the Ipswich watershed, the densest development is in the most distant headwaters, allowing ample opportunity for $\mathrm{N}$ removal along surface water flow paths, which include many wetland-dominated reaches (Wollheim et al. 2008). Historical legacies may also contribute to high contemporary $\mathrm{N}$ removal (as accumulating biomass) because previous agricultural activity depleted $\mathrm{N}$ in upland soils (Foster et al. 2003b; Bain et al. 2012), allowing modern accumulation of incoming N (Magill et al. 1997). Floodplain wetlands may also be $\mathrm{N}$ depleted because they were extensively hayed through the agricultural period (Foster et al. 2003a; Donahue 2004). As a result, modern $\mathrm{N}$ inputs may be sequestered by vegetation regrowth and soil organic $\mathrm{N}$ accumulation.

Our reconstruction of the Ipswich $\mathrm{N}$ budget through time is similar to a recent analysis of the Narragansett Bay, RI, USA watershed (Vadeboncoeur et al. 2010). The export coefficient model of Vadeboncoeur et al. (2010) assumed watershed $\mathrm{N}$ removal between 80 and $90 \%$, similar to our measurements from the Ipswich River (80-95 \%; Fig. 6). A wide range of other watershed-scale studies have also demonstrated a high percentage of annual $\mathrm{N}$ removal over a wide range of watershed characteristics and $\mathrm{N}$ source types (Boyer et al. 2002; Howarth et al. 2012). As a result, we believe that the $\mathrm{N}$ removal service of the Ipswich River is similar to other watersheds.

\section{Uncertainties in Historical Analyses}

The ability to reconstruct ecosystem service sources over time is limited by the available historical and spatially resolved data. Modern observations extend back to different points in time, e.g., discharge to 1934 , water supply to 1868 , fertilizer to 1948, atmospheric deposition to 1982 , N removal to 1994, and required models with underlying assumptions to extend further. For the purpose of this analysis, we generally believe that the information is sufficient to capture longer-term trends in key ecosystem services that impact material budgets. An exception is the role of food provisioning historically, which may have led to substantial material transfer across watershed boundaries, including both imports (e.g., feed for dairy cattle) or exports (e.g., food products). Integration of archival information and collaborations among social scientists, historians, and environmental 
scientists offers a chance for constraining such estimates (Bain et al. 2011; Zadorozhny et al. 2013), but is beyond the scope of this study. For example, synthesis of archived town histories, historical maps, and US Population and Agricultural Census information could begin to isolate the relative importance of local vs. exported food provision and $\mathrm{N}$ imports/ exports over time (Donahue 2004; Pastore et al. 2010). Integration of historical land use maps and climate reconstructions (Foster et al. 2003a) with spatially distributed hydrologic models, archival records, and biogeophysical data sets such as sediment cores (Bain et al. 2012) would allow the evaluation of assumptions of uniform runoff and test estimates of changing nutrient fluxes over time. As historical analysis becomes more quantitative (Tuchin 2008), the uncertainty in input variables and historical interpretation can be tested more formally.

\section{Socioecological Feedbacks and Regionalization}

Environmental feedbacks between natural and human systems (socioecological feedbacks) are potentially an important mechanism by which coupled human-natural systems evolve over time (Liu et al. 2007). However, it is not clear when, where, and over what spatial and temporal scales such feedbacks arise. When feedbacks are weak or nonexistent, societal change simply acts as a driver on environmental conditions (Lambin and Meyfroidt 2009). Time series reconstruction of watershed ecosystem service activity (Figs. 3 and 7) may contain information regarding these dynamics. A preliminary categorization of causes of ecosystem service change over time in the Ipswich River is provided in Table 2.

Dynamics from the Ipswich River watershed demonstrate how a socioecological feedback emerges. Water withdrawals impacted summer low flows in the Ipswich River over the last 20 years, resulting in dry river reaches, fish kills, and concerns about seasonally inadequate water supply (Zarriello and Ries 2000; Glennon 2002). Publicity sparked by the Ipswich River Watershed Association led to articles in regional newspapers and listing of the Ipswich River as one of USA's top 10 endangered rivers by the nonprofit group, American Rivers. This negative publicity led to widespread public perception of the problem, while research confirmed that a major cause was water withdrawals (Zarriello and Ries 2000).

Socioecological feedbacks within the watershed arose over several spatial and temporal scales. At local scales, towns implemented short-term water bans more frequently to limit residential water use during droughts (Hill and Polsky 2007). This response acknowledges that trade-offs exist among ecosystem services (Bennett et al. 2009): a green lawn (a cultural ecosystem service) vs. healthy fish populations and sufficient water supply. A longer-term, broader-scale feedback was the connection in 2006 of one of the major internal Ipswich water users, the Town of Reading, to the regional water supplier for Boston and its nearby suburbs (the MWRA). Reading was the major water user in the upper Ipswich watershed and contributed disproportionately to the low-flow problem (Zarriello and Ries 2000). This feedback contributes to the greater import and reduced export and local use in recent years (Fig. 3). A cross-scale solution was made possible by existing nearby engineering infrastructure that made it cost-effective. Thus, impacts of human activity are transferred across scale, i.e., "passing the buck" (Rothman 1998; Suri and Chapman 1998), increasing the footprint of humans living in the watershed (Sanderson et al. 2002; Hoekstra and Chapagain 2007).

Other possible socioecological feedbacks that could have limited demand for local water have not emerged. Examples include limits to residential development and population growth. A potential consequence of Reading's decision to import water is that water-related limits to growth have been removed, possibly increasing future, local impacts through expanded residential development, impervious surfaces, storm runoff, and reduced water quality, as was the case in the past with denser suburbs nearer to Boston (Weiskel et al. 2005).

Water supply feedbacks provide the only clear evidence of negative socioecological feedback in this watershed (Table 2). Conversion from septic to sewer waste management in denser watershed communities in the 1960s and 1970s could have been a response to degrading water quality within the watershed. However, we have no evidence this was the basis for developing sewer systems. Instead, sewer development was likely part of a broader national scale response to water quality degradation via the Clean Water Act in 1972, which provided billions of US dollars for the construction of centralized wastewater systems (Armstrong 1976). At least at the local scale, this conversion was the result of larger socioeconomic drivers (as opposed to withinsystem feedback response).

\section{The Evolution of Ecosystem Services in Urbanizing Watersheds}

An idealized model of ecosystem service evolution for watersheds in urban regions is shown in Fig. 8. The model presents a time line of the dominant type and magnitude of ecosystem services for a given watershed as urbanization increases. Newly inhabited watersheds or those distant from urban centers are rural while older, more developed watersheds are urban. Those in between are suburban. We hypothesize that suburban watersheds are hotspots of ecosystem service sources because (1) natural ecosystems remain relatively intact and retain capacity to generate services, (2) 
Table 2 Description of major ecosystem service dynamics over time in the Ipswich watershed

\begin{tabular}{|c|c|c|c|c|}
\hline $\begin{array}{l}\text { Ecosystem } \\
\text { service type }\end{array}$ & Description & $\begin{array}{l}\text { Year of } \\
\text { response }\end{array}$ & $\begin{array}{l}\text { Driver/ } \\
\text { feedback }^{\mathrm{a}}\end{array}$ & Explanation \\
\hline \multirow[t]{4}{*}{ Water provision } & $\begin{array}{l}\text { Salem/Beverly construct } \\
\text { Longham Reservoir }\end{array}$ & 1895 & $\begin{array}{l}\text { Feedback } \\
\text { (positive) }\end{array}$ & $\begin{array}{l}\text { Expanding Ipswich water supply during } 1890 \text { s drought; } \\
\text { allows continued growth outside basin and leads to } \\
\text { increased withdrawals later }\end{array}$ \\
\hline & $\begin{array}{l}\text { Salem/Beverly construct } \\
\text { canal to Ipswich River } \\
\text { main stem }\end{array}$ & 1915 & $\begin{array}{l}\text { Feedback } \\
\text { (positive) }\end{array}$ & Growing population and drought period of $1910 \mathrm{~s}$ \\
\hline & $\begin{array}{l}\text { City of Lynn required to } \\
\text { reduce exports from the } \\
\text { Ipswich }\end{array}$ & $\sim 1980$ & Feedback? & $\begin{array}{l}\text { State requires reduced withdrawal by City of Lynn, outside } \\
\text { the basin }\end{array}$ \\
\hline & $\begin{array}{l}\text { Reduced export and internal } \\
\text { use of water and greater } \\
\text { imports }\end{array}$ & 2000-present & $\begin{array}{l}\text { Feedback } \\
\text { (negative) }\end{array}$ & $\begin{array}{l}\text { Low-flow conditions, and pollution lead to towns } \\
\text { transitioning to external water sources }\end{array}$ \\
\hline \multirow[t]{2}{*}{$\begin{array}{l}\text { Nitrogen } \\
\text { regulating }\end{array}$} & $\begin{array}{l}\text { Reduced waste } \mathrm{N} \text { input due } \\
\text { to sewer construction and } \\
\text { export }\end{array}$ & $1965-1975$ & Driver? & $\begin{array}{l}\text { Flurry of sewer building activity in denser communities } \\
\text { possibly due to federal fund availability in Clean Wate } \\
\text { Act }\end{array}$ \\
\hline & Reduced fertilizer inputs & $\sim 1980-1983$ & Driver & Increasing fertilizer prices due to oil shock and recession \\
\hline
\end{tabular}

${ }^{\text {a }}$ Dynamics are shaped by socioeconomic drivers or socioecological feedbacks. Drivers are forces that originate outside the system, while feedbacks are forces that originate within the system. The immediate source of driver or feedback is explained

they have increasing local populations that require ecosystem services, and (3) they contain legacies of ecosystem service sources used by nearby urban centers.

Watersheds in a pristine state and uninfluenced by urban centers provide a minimal source of ecosystem services that mainly benefit small, local populations, with little impact to watershed material budgets (Fig. 8). As population and associated ecosystem service demand from immediate or otherwise connected regions increases, rural watersheds start to act as a source of ecosystem services to more densely populated areas, with associated transfer of materials (e.g., Ipswich water 1868-1940; Fig. 3b). If urbanization expands into the source watershed, its role as a source of ecosystem services increases as greater local population also benefits (e.g., Ipswich water 1940-1980; Fig. 3b). The need for regulating ecosystem services also begins to increase during this stage as pollutants associated with population increase and sufficient ecosystem processing capacity remains (Fig. 7). If population in the source watershed continues to increase, demand may either outstrip the watersheds ability to provide services or services start to degrade indirectly. As a result, additional ecosystem service sources are sought from more distant watersheds or replaced with engineered solutions and dependence on locally generated services declines (e.g., Ipswich water 1990-2010; Fig 3b).

The general outline of this conceptual model could be applied to watersheds in general, but specific locations would have unique curve shapes, time lines and dominant services. For watersheds draining urban cores, the time line is compressed and occurred long ago. Although an export phase may not have occurred, services were at first locally derived. For example, Boston supplied water from within its boundaries until 1795 and abandoned it as this supply was overwhelmed, while excess nutrients in wastewater were historically loaded to local rivers, but then replaced by sewage treatment plants, which now export directly to the coastal zone (MDC 1984; Tarr et al. 1984). Agricultural watersheds are food provisioning to distant urban regions in the modern era, maintaining a peak or plateau of their provisioning curve towards the left of the $x$-axis in Fig. 8. A sustainably managed watershed, by managing demand and/or preventing degradation of sources, may also continue to provide ecosystem services at a plateau (e.g., remote water supply or recreation).

The model proposes similar trajectories for cultural ecosystem services. For example, recreational services provided by a rural watershed increase with visitation from urbanites from outside the watershed. Such services continue to increase with suburbanization as local population also begins to benefit. As urbanization continues, local recreational services may decline due to degraded opportunities. The contemporary Ipswich River remains a popular destination for canoeing (Glennon 2002). Though trends in this recreational activity over time are unavailable, low flows from excessive summer water use reduces canoeing opportunities, suggesting that, if low flows become more common, this recreational service would begin to decline. However, if feedbacks reduce impacts, recreational services may be maintained even as urbanization progresses.

Our analysis is inherently spatial in that it focuses on watershed boundaries and cross-boundary material flows. Although we only reconstructed temporal patterns for a single watershed, such analyses could be expanded to create ecosystem service source curves for multiple watersheds to 
Fig. 8 Conceptual model of how ecosystem services $(E S)$ supplied by watersheds draining urban regions may evolve

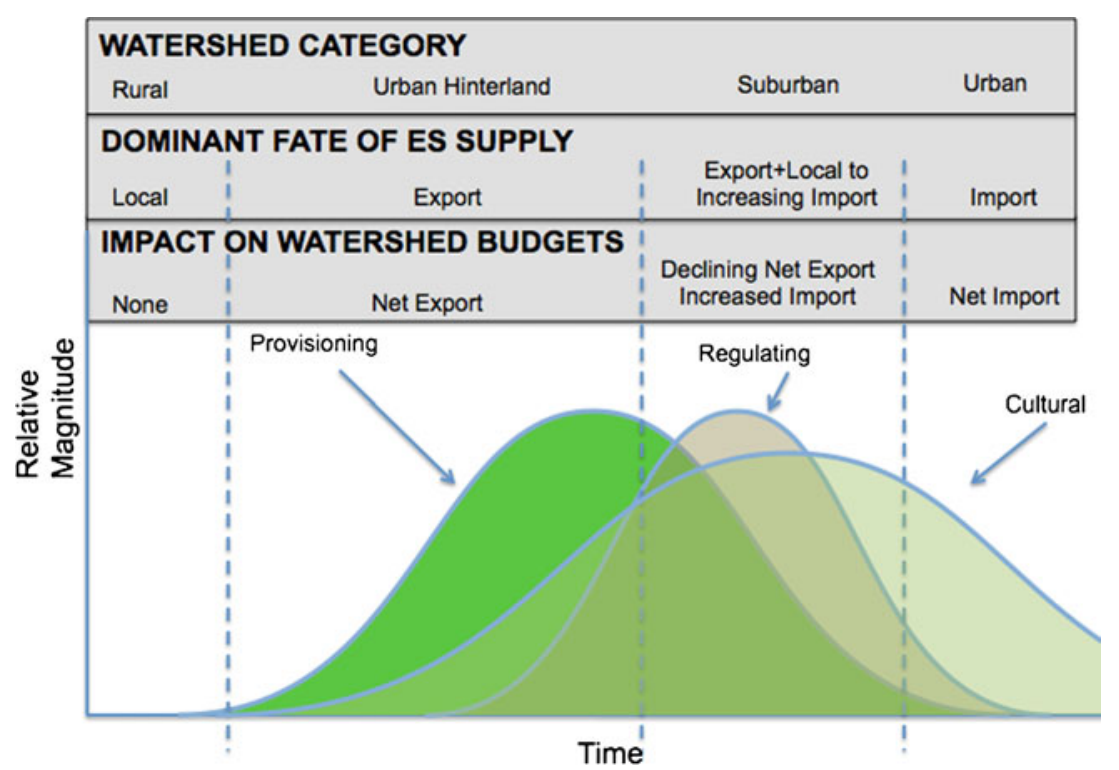

understand interacting geographical patterns of demands and sources, impacts to water and biogeochemical budgets, the role of engineering infrastructure, and sustainability at local and regional scales. For example, Beier et al. (2008) used both gridded and watershed-scale regional analyses to identify localized regions of ecosystem service vulnerability due to elevated demands. Analyses spanning the urban/rural gradient in a space for time substitution could also be used to test the hypothesis that suburban watersheds are ecosystem service hotspots.

\section{The Value of Ecosystem Services}

The ecosystem services we considered provide direct (water supply) and indirect ( $\mathrm{N}$ removal) benefits to the society (Farber et al. 2006). Quantifying the value of these benefits through time is beyond the scope of our analysis. Quantification is difficult because values vary through time and space (Fisher et al. 2011), and no rigorous valuation studies have been conducted for this watershed, even for the modern era (but for a qualitative valuation, see Farber et al. 2006). The value of ecosystem services provided by the watershed would change over time as a function of the quantity of different services and their unit value at each point in time. However, we suggest that, if suburban watersheds are focal points of ecosystem service sources (Fig. 8), it follows that they are also concentrated areas of ecosystem service value. The ongoing decline as a water supply source suggests that the value of the Ipswich watershed for this important ecosystem service is starting to decline, as predicted by Farber et al. (2006). The Town of Reading paid 1.7 million dollars to import water via the MWRA in 2012 (MWRA FY 2012 Assessment Rates; http://www.mwra.state.ma.us/finance/ rates/aboutrates.htm), much of which would not have been spent if still relying on local water. However, the river ecosystem itself is healthier as a result, so the value of other ecosystem services is maintained or enhanced. A comprehensive valuation of ecosystem services across urban/rural gradients would help assess these trade-offs, aid in planning as climate and land use change, and identify sustainable levels of development that maintains desired levels of ecosystem service supply.

\section{Conclusions}

Societal demand for ecosystem services increases in proportion to human activity. Typically, demand in densely populated areas outstrips the ability of local systems to provide services. Time series of ecosystem service sources at watershed scales partitioned into whether they are locally or distally supplied or used can help identify impacts and feedbacks responsible for changing patterns over time. Society generally responds to mismatches between ecosystem service demand and available sources by moving across scale, i.e., through regionalization or increasing footprints. Ecosystem services previously provided by urbanizing watersheds may be abandoned. While resource use and impact at the local scale may be alleviated, the impact could continue to expand globally. Sustainable local management is an alternative, but may require difficult choices that involve constraining human actions. Suburban watersheds are promising systems in which to understand such dynamics because ecosystem service sources and utilization are often still in close proximity. Understanding the societal characteristics that lead to sustainable local solutions could help develop approaches for managing our global environment, where cross-scale solutions are no longer available. 
Acknowledgments This work was funded by the National Science Foundation (NSF) grants NSF-OCE-1058747 and OCE 1238212 (Plum Island LTER) and NSF-CHN-0709685. We thank Kerry Mackin for compiling the recent water use data from MA-DEP. We thank Dan Bain for the helpful discussions and comments that improved this paper. We thank Colin Polsky, Gil Pontius, and Jon Duncan for the discussions that aided in the development of this manuscript, as well as the helpful comments by Laurel Larsen and two anonymous reviewers.

Open Access This article is distributed under the terms of the Creative Commons Attribution License which permits any use, distribution, and reproduction in any medium, provided the original author(s) and the source are credited.

\section{References}

Alexander, R.B., and R.A. Smith. 1990. County-level estimates of nitrogen and phosphorus fertilizer use in the United States, 1945 to 1985. Reston: USGS

Armstrong, E.L. 1976. History of public works in the United States: 1776-1976. Chicago: American Public Works Association.

Bahn, H.M., and R.L. Christensen. 1979. Regional self-sufficiency in food production-The New England states. Journal of the Northeastern Agricultural Economics Council 8: 1-5.

Bain, D., M.B. Green, J. Campbell, J. Chamblee, J. Fraterrigo, S.S. Kaushal, S. Martin, T. Jordan, A. Parolari, W.V. Sobczak, D.E. Weller, W.M. Wollheim, E. Boose, J. Duncan, G. Gettel, B. Hall, P. Kumar, J. Thompson, J. Vose, E. Elliott, and D. Leigh. 2012. Legacies in material flux: Structural catchment changes pre-date long-term studies. Bioscience 62: 575-584.

Bain, D.J., J.A. Arrigo, M.B. Green, B.A. Pellerin, and C.J. Vorosmarty. 2011. Historical legacies, information and contemporary water science and management. Water 3: 566-575.

Beier, C., T. Patterson, and F.S. Chapin. 2008. Ecosystem services and emergent vulnerability in managed ecosystems: A geospatial decision-support tool. Ecosystems 11: 923-938.

Bennett, E., G. Peterson, and L. Gordon. 2009. Understanding relationships among multiple ecosystem services. Ecology Letters 12: 1-11.

Bernot, M., and W.K. Dodds. 2005. Nitrogen retention, removal, and saturation in lotic ecosystems. Ecosystems 8: 442-453.

Blanton, P., and W.A. Marcus. 2009. Railroads, roads and lateral disconnection in the river landscapes of the continental United States. Geomorphology 112: 212-227.

Bowen, J.L., and I. Valiela. 2001. Historical changes in atmospheric nitrogen deposition to Cape Cod, Massachusetts, USA. Atmospheric Environment 35: 1039-1051.

Boyer, E.W., C.L. Goodale, N.A. Jaworsk, and R.W. Howarth. 2002. Anthropogenic nitrogen sources and relationships to riverine nitrogen export in the northeastern USA. Biogeochemistry 57: 137-169.

Brauman, K., G.C. Daily, T. Duarte, and H.A. Mooney. 2007. The nature and value of ecosystem services: An overview highlighting hydrologic services. Annual Review of Environment Resources 32: 67-98.

Burges, S.J., M.S. Wigmosta, and J.M. Meena. 1998. Hydrological effects of land-use change in a zero-order catchment. Journal of Hydrological Engineering 3: 86-97.

Chapin, F.S., S.R. Carpenter, G.P. Kofinas, C. Folke, N. Abel, W.C. Clark, P. Olsson, D.M.S. Smith, B. Walker, O.R. Young, F. Berkes, R. Biggs, J.M. Grove, R.L. Naylor, E. Pinkerton, W. Steffen, and F.J. Swanson. 2009. Ecosystem stewardship: Sustainability strategies for a rapidly changing planet. Trends in Ecology \& Evolution 25: 241-249.
Claessens, L., C. Hopkinson, E. Rastetter, and J. Vallino. 2006. Effect of historical changes in land use and climate on the water budget of an urbanizing watershed. Water Resources Research 42, W03426.

Diaz, R.J., and R. Rosenberg. 2008. Spreading dead zones and consequences for marine ecosystems. Science 321: 926-929.

Donahue, B. 2004. The great meadow: Farmers and the land in colonial Concord. New Haven: Yale University Press, 344 p.

Doyle, M.W. 2005. Incorporating hydrologic variability into nutrient spiraling. Journal of Geophysical Research 110, GO1003.

Doyle, M. W. 2012. America's rivers and American experiment. Journal of the American Water Resources Association 18. doi:10.1111/j.1752-1688.2012.00652.x.

Farber, S., R. Costanza, D.L. Childers, J. Erickson, K. Gross, M. Grove, C.S. Hopkinson, J. Kahn, S. Pincetl, A. Troy, P. Warren, and M.V. Wilson. 2006. Linking ecology and economics for ecosystem management. Bioscience 56: 121-133.

Fisher, B., I. Bateman, and R. Turner. 2011. Valuing ecosystems services: Benefits, values, space and time. Ecosystem Services Economics Working Paper Series No. 3, UNEP.

Foster, D., B. Hall, and J. Burk. 2003a. Massachusetts historical landcover and census data. Harvard Forest Data Archive HF014.

Foster, D., F. Swanson, J. Aber, I. Burke, N. Brokaw, D. Tilman, and A. Knapp. 2003b. The importance of land-use legacies to ecology and conservation. Bioscience 53: 77-88.

Galloway, J.N., J.D. Aber, J.W. Erisman, S.P. Seitzinger, R.W. Howarth, E.B. Cowling, and B.J. Cosby. 2003. The nitrogen cascade. Bioscience 53: 341-356.

Gedney, N., P.M. Cox, R.A. Betts, O. Boucher, C. Huntingford, and P.A. Stott. 2006. Detection of a direct carbon dioxide effect in continental river runoff records. Nature 439: 835-838.

Glennon, R. 2002. Water follies: Groundwater pumping and the fate of America's freshwater. Washington, DC: Island Press.

Grimm, N.B., S.H. Faeth, N.E. Golubiewski, C.L. Redman, J.G. Wu, X.M. Bai, and J.M. Briggs. 2008a. Global change and the ecology of cities. Science 319: 756-760.

Grimm, N.B., D. Foster, P. Groffman, J.M. Grove, C.S. Hopkinson, K.J. Nadelhoffer, D.E. Pataki, and D.P.C. Peters. 2008b. The changing landscape: Ecosystem responses to urbanization and pollution across climatic and societal gradients. Frontiers in Ecology and the Environment 6: 264-272.

Groffman, P., N. Law, K. Belt, L. Band, and G. Fisher. 2004. Nitrogen fluxes and retention in urban watershed ecosystems. Ecosystems 7: 393-403.

Hall, B., G. Motzkin, D.R. Foster, M. Syfert, and J. Burk. 2002. Three hundred years of forest and land-use change in Massachusetts, USA. Journal of Biogeography 29: 1319-1335.

Hill, T., and C. Polsky. 2007. Suburbanization and drought: A mixed method vulnerability assessment in rainy Massachusetts. Environmental Hazards 7: 291-301.

Hoekstra, A.Y., and A.K. Chapagain. 2007. Water footprints of nations: Water use by people as a function of their consumption pattern. Water Resources Management 21: 35-48.

Hopkinson, C.S., and J.J. Vallino. 1995. The relationship among man's activities in watersheds and estuaries: A model of runoff effects on patterns of estuarine community metabolism. Estuaries and Coasts 18: 598-621.

Howarth, R.W., D. Swaney, G. Billen, J. Garnier, B. Hong, C. Humborg, P. Johnes, C.M. Morth, and R. Marino. 2012. Nitrogen fluxes from the landscape are controlled by net anthropogenic nitrogen inputs and by climate. Frontiers in Ecology and the Environment 10: 37-43. doi:10.1890/100178.

Huntington, T.G., A. Richardson, K.J. McGuire, and K. Hayhoe. 2009. Climate and hydrological changes in the northeastern United States: Recent trends and implications for forested and aquatic ecosystems. Canadian Journal of Forest Research 39: 199-212. 
Jones, J.A., F.J. Swanson, B.C. Wemple, and K.U. Snyder. 2000. Effects of roads on hydrology, geomorphology, and disturbance patches in stream networks. Conservation Biology 14: 76-85.

Karl, T.R., and R.W. Knight. 1998. Secular trends of precipitation amount, frequency, and intensity in the United States. Bulletin of the Meteorlogical Society 79.

Kaushal, S.S., P.M. Groffman, L.E. Band, C.A. Shields, R.P. Morgan, M.A. Palmer, K.T. Belt, C.M. Swan, S.E.G. Findlay, and G.T. Fisher. 2008. Interaction between urbanization and climate variability amplifies watershed nitrate export in Maryland. Environmental Science and Technology 42: 5872-5878.

Kirwan, M.L., G.R. Guntenspergen, A. D’Alpaos, J.T. Morris, S.M. Mudd, and S. Temmerman. 2010. Limits on the adaptability of coastal marshes to rising sea level. Geophysical Research Letters 37.

Lambin, E., and P. Meyfroidt. 2009. Land use transitions: Socioecological feedback versus socio-economic change. Land Use Policy 27: 108-118.

Lerner, D. 2002. Identifying and quantifying urban recharge: A review. Hydrogeology Journal 10: 143-152.

Likens, G.E., and F.H. Bormann. 1974. Linkages between terrestrial and aquatic ecosystems. Bioscience 24: 447-456.

Liu, J., T. Dietz, S.R. Carpenter, C. Folke, M. Alberti, C.L. Redman, S.H. Schneider, E. Ostrom, A.N. Pell, J. Lubchenco, W.W. Taylor, Z. Ouyang, P. Deadman, T. Kratz, and W. Provencher. 2007. Coupled human and natural systems. Ambio 36: 639-649.

Longley, F.F. 1916. The water supply of Salem and Beverly. Journal of the New England Water Works Association 30: 35-45.

Lookingbill, T., S.S. Kaushal, A. Elmore, R. Garnder, K. Eshleman, R. Hilderbrand, R. Morgan, W.R. Boynton, M.A. Palmer, and W. Dennison. 2009. Altered ecological flows blur boundaries in urbanizing watersheds. Ecology and Society 14: 10.

Magill, A.H., J.D. Aber, J.J. Hendricks, R.D. Bowden, J.M. Melillo, and P.A. Steudler. 1997. Biogeochemical response of forest ecosystems to simulated chronic nitrogen deposition. Ecological Applications 7: 402-415.

MDC. 1984. A history of the development of the Metropolitan District Commission (Boston) water supply system. Prepared by Wallace, Floyd, Associates Inc.

Millenium Ecosystem Assessment Board. 2005. Ecosystems and human well-being: Current state and trends, volume 1. Washington, DC: Island Press.

Mulholland, P.J., A.M. Helton, G.C. Poole, R.O. Hall, S.K. Hamilton, B.J. Peterson, J.L. Tank, L.R. Ashkenas, L.W. Cooper, C.N. Dahm, W.K. Dodds, S.E.G. Findlay, S.V. Gregory, N.B. Grimm, S.L. Johnson, W.H. McDowell, J.L. Meyer, H.M. Valett, J.R. Webster, C.P. Arango, J.J. Beaulieu, M.J. Bernot, A.J. Burgin, C.L. Crenshaw, L.T. Johnson, B.R. Niederlehner, J.M. O/ 'Brien, J.D. Potter, R.W. Sheibley, D.J. Sobota, and S.M. Thomas. 2008. Stream denitrification across biomes and its response to anthropogenic nitrate loading. Nature 452: 202 205.

Nelson, E., G. Mendoza, J. Regetz, S. Polasky, H. Tallis, D. Cameron, K.M.A. Chan, G.C. Daily, J. Goldstein, P.M. Kareiva, E. Lonsdorf, R. Naidoo, T.H. Ricketts, and M. Shaw. 2009. Modeling multiple ecosystem services, biodiversity conservation, commodity production, and tradeoffs at landscape scales. Frontiers in Ecology and the Environment 7: 4-11.

Nixon, S. W., B. A. Buckley, S. L. Granger, L. A. Harris, A. J. Oczkowski, R. W. Fulweiler, and L. W. Cole. 2008. Nitrogen and phosphorus inputs to Narragansett Bay: Past, present and future. In Science of ecosystem-based management, eds. A. Desbonnet and B. A. Costa-Pierce. New York: Springer.

Pastore, C., M. Green, D. Bain, A. Munoz-Hernandez, C.J. Vorosmarty, J. Arrigo, S. Brandt, J. Duncan, F. Greco, H. Kim, S. Kumar, M. Lally, A. Parolari, B.A. Pellerin, N. Salant, A. Schlosser, and K. Zalzal. 2010. Tapping environmental history to recreate America's colonial hydrology. Environmental Science and Technology 44: 8798-8803. doi:10.1021/es102672c.

Paul, M.J., and J.L. Meyer. 2001. Streams in the urban landscape. Annual Review of Ecology and Systematics 32: 333-365.

Peet, J.R. 1969. Spatial expansion of commercial agriculture in 19th century-A Thunen, Jhv interpretation. Economic Geography 45: 283-301.

Peters, D.P.C., P.M. Groffman, K.J. Nadelhoffer, N.B. Grimm, S.L. Coffins, W.K. Michener, and M.A. Huston. 2008. Living in an increasingly connected world: A framework for continental-scale environmental science. Frontiers in Ecology and the Environment 6: 229-237.

Rockstrom, J., W. Steffen, K. Noone, A. Persson, F. Chapin, E. Lambin, T. Lenten, M. Scheffer, C. Folke, et al. 2009. A safe operating space for humanity. Nature 461: 472-475.

Rothenberg, W. B. 1992. From market-places to a market economy: The transformation of rural Massachusetts 1750-1850. Chicago: University of Chicago Press.

Rothman, D.S. 1998. Environmental Kuznets curves-Real progress or passing the buck? A case for consumption-based approaches. Ecological Economics 25: 177-194.

Ruddy, B. C., D. L. Lorenz, and D. K. Mueller. 2006. County-level estimates of nutrient inputs to the land surface of the conterminous United States, 1982-2001. USGS scientific investigations report 2006-5012. Available at http://pubs.usgs.gov/sir/2006/5012/

Runkel, R., C. Crawford, and T. Cohn. 2004. Load Estimator (LOADEST): A Fortran program for estimating constituent loads in streams and rivers. USGS techniques and methods book 4, chapter A5. Available at http://pubs.usgs.gov/tm/2005/tm4A5/

Sammel, E. A. 1967. Water resources of the Parker and Rowley River basins Massachusetts. USGS hydrologic investigation atlases. Available at http://pubs.er.usgs.gov/publication/ha247.

Sanderson, E.W., M. Jaiteh, M.A. Levy, K.H. Redford, A.V. Wannebo, and J. Woolmer. 2002. The human footprint and the last of the wild. Bioscience 52: 891-904.

Schneider, L.C., and R. Pontius. 2001. Modeling land use change in the Ipswich watershed, Massachusetts, USA. Agriculture, Ecosystems and Environment 85: 83-94.

Seitzinger, S., J.A. Harrison, J.K. Bohlke, A.F. Bouwman, R. Lowrance, B.J. Peterson, C.R. Tobias, and G. Van Drecht. 2006. Denitrification across landscapes and waterscapes: A synthesis. Ecological Applications 6: 1051-1076.

Stewart, R. J., W. M. Wollheim, M. Gooseff, M. A. Briggs, J. M. Jacobs, B. J. Peterson, and C. S. Hopkinson. 2011. Separation of River Network Scale Nitrogen Removal Among Main Channel and Two Transient Storage Compartments. Water Resources Research 47, W00J10. doi:10.1029/2010WR009896.

Suri, V., and D. Chapman. 1998. Economic growth, trade and energy: Implications for the environmental Kuznets curve. Ecological Economics 25: 195-208.

Tarr, J., J. McCurley, F. McMichael, and T. Yosie. 1984. Water and wastes: A retrospective assessment of wastewater technology in the United States, 1800-1932. Technology and Culture 25: 226263.

Tuchin, P. 2008. Arise 'cliodynamics'. Nature 454: 34-35.

US Census. 1925. Census of agriculture. United States Census Bureau.

US Census. 1998. Table 2. Population of the 24 urban places: 1790. Available at http://www.census.gov/population/www/documentation/ twps0027/tab02.txt.

Vadeboncoeur, M., S.P. Hamburg, and D. Pryor. 2010. Modeled nitrogen loading to Narragansett Bay: 1850 to 2015. Estuaries and Coasts 33: 1113-1127. doi:10.1007/s12237-010-9320-3.

Valiela, I., G. Collins, J. Kremer, K. Lajtha, M. Geist, B. Seely, J. Brawley, and C.H. Sham. 1997. Nitrogen loading from coastal watersheds to receiving estuaries: New method and application. Ecological Applications 7: 358-380. 
Van Breemen, N., E.W. Boyer, C.L. Goodale, N.A. Jaworski, K. Paustian, S.P. Seitzinger, K. Lajtha, B. Mayer, D. Van Dam, R.W. Howarth, K.J. Nadelhoffer, M. Eve, and G. Billen. 2002. Where did all the nitrogen go? Fate of nitrogen inputs to large watersheds in the northeastern USA. Biogeochemistry 57: 267-293.

Vitousek, P.M., and R.W. Howarth. 1991. Nitrogen limitation on land and in the sea: How can it occur? Biogeochemistry 13: 87-115.

Weiskel, P., L. Barlow, and T. Smieszek. 2005. Water resources and the urban environment, Lower Charles River Watershed, Massachusetts, 1630-2005. Available at http://pubs.usgs.gov/circ/2005/1280/.

Weiskel, P., R. M. Vogel, P. A. Stevees, P. J. Zariello, L. A. DeSimone, and K. G. Ries III. 2007. Water use regimes: Characterizing direct human interaction with hydrologic systems. Water Resource Research 43(4). doi:10.1029/2006WR005062.

Williams, M., C. Hopkinson, E. Rastetter, J. Vallino, and L. Claessens. 2005. Relationships of land use and stream solute concentrations in the Ipswich River basin, northeastern Massachusetts. Water, Air, and Soil Pollution 161: 55-74.
Williams, M., C.H. Hopkinson, E.B. Rastetter, and J. Vallino. 2004. N budgets and aquatic uptake in the Ipswich R. basin, northeastern Massachusetts. Water Resources Research 40, W11201.

Wollheim, W.M., B.A. Pellerin, C.J. Vorosmarty, and C.S. Hopkinson. 2005. N retention in urbanizing headwater catchments. Ecosystems 8: 871-884.

Wollheim, W. M., B. J. Peterson, C. J. Vorosmarty, C. Hopkinson, and S. A. Thomas. 2008. Dynamics of N removal over annual time scales in a suburban river network. Journal of Geophysical Research-Biogeosciences G03038. doi:10.1029/2007JG000660.

Zadorozhny, V., P. Mannin, D.J. Bain, and R. Mostern. 2013. Collaborative for historical information and analysis: Vision and work plan. Journal of World-Historical Information 1: 1-14.

Zarriello, P. J. and K. G. Ries. 2000. A precipitation-runoff model for analysis of the effects of water withdrawals on streamflow, Ipswich River Basin, Massachusetts. Water-Resources Investigation Report 00-4029, United States Geological Survey, Northborough, Massachusetts. 